\title{
Disruption of the AKT/MTOR pathway by Leishmania major promastigotes
}

\author{
Christine Matte, Albert Descoteaux \\ From Institut Pasteur International Network Annual Scientific Meeting \\ Hong Kong. 22-23 November 2010
}

Signaling through the Akt/mammalian target of rapamycin (mTOR) pathway plays a pivotal role in the regulation of multiple cellular processes, including proliferation, apoptosis, protein synthesis and autophagy. It is therefore a major target of microbial infections and tumors. Protozoa of the Leishmania genus cause a wide spectrum of diseases in humans, termed leishmaniases, with clinical manifestations ranging from self-healing skin ulcers to life-threatening visceral disease. These parasites primarily infect macrophages and are renowned for their ability to sabotage host-cell signal transduction pathways. Here, we report that infection of Balb/c bone marrow-derived macrophages with the promastigote stage of Leishmania major results in rapid, time-dependent degradation of key components of the Akt/mTOR axis, including Akt, mTOR and the tuberous sclerosis complex-2 (TSC-2). Disruption of the Akt/mTOR pathway by L. major is dependent on the surface metalloprotease gp63, an important virulence factor of the parasite, and appears to be strain- and species-specific. The consequences of the degradation of key intermediates in the Akt/mTOR pathway on downstream responses are currently being investigated. These studies highlight a novel mechanism by which $L$. major interferes with macrophage functions and responses and will provide a better understanding of Leishmania pathogenesis.

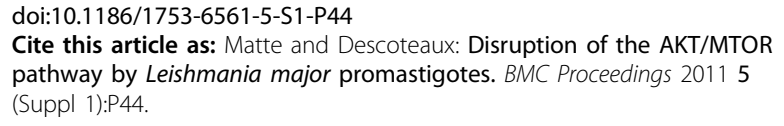

* Correspondence: christine.matte@iaf.inrs.ca

INRS-Institut Armand-Frappier, Laval, Quebec, Canada, H7V 1B7
Submit your next manuscript to BioMed Central and take full advantage of:

- Convenient online submission

- Thorough peer review

- No space constraints or color figure charges

- Immediate publication on acceptance

- Inclusion in PubMed, CAS, Scopus and Google Scholar

- Research which is freely available for redistribution
() Biomed Central

\section{Biomed Central}

